\title{
Makna-Makna Preposisi dalam Bahasa Arab
}

\section{Sabaruddin Garancang ${ }^{1}$}

${ }^{1}$ Universitas Islam Negeri Alauddin Makassar, Indonesia E-mail : ${ }^{1}$ sabaruddin_garancang@yahoo.com

المقدمة:

$$
\begin{aligned}
& \text { المدف من هذه الدراسة هو التعبير عن المعانى لحروف الجحر الثلاثة خاصة وهي من و الي و } \\
& \text { في. و تلك حروف الجر الثلاثة تسمي عادة بالحروف التي تنصل باسم المكان او باسم } \\
& \text { يماثله في الجملة. معالي حروف الجر متنوعة وحرف "من" اولا وهي ما يدل علي ابتداء } \\
& \text { الغاية والتبعيض و التبيين والتعليل والبدل والفصل والجماوزة والاصاق و الظرف و } \\
& \text { الاستعلاء والقسم والتجريد والتاكيد. } \\
& \text { وحرف الجر "اللي" لها معان كذالك وهي انتهاء الغاية والمصاحبة واللام والظرفية و التبيين } \\
& \text { والتأكيد والتأدية اي ما يسبب الفعل اللازم الي المعني المتعدى. } \\
& \text { واما حرف الجر "في" فمعناه هو ما يدل علي الظرفية والمصاحبة والتعليل والاستعلاء } \\
& \text { والمقايسة والاستعانة وانتهاء الغاية والتأكيد و معني "عن". والتعمق في هذه المعاني مهم } \\
& \text { جدا في فهم المتون العربية المتنوعة وترجمتها. }
\end{aligned}
$$

Abstrak : Tujuan dari penelitian ini adalah untuk mengungkapkan makna dari tiga preposisi, terutama dari, ke, dan di. Dan ketiga preposisi ini biasanya disebut dengan huruf-huruf yang menghubungkan nama tempat atau nama yang mirip dalam kalimat. Arti dari preposisi bervariasi, dan huruf "dari" pertama, yang menunjukkan awal dari akhir, subdivisi, penjelasan, penalaran, substitusi, pemisahan, pelanggaran, adhesi, kata keterangan, superioritas, sumpah, abstraksi, dan penekanan. Kata depan "untuk" memiliki arti yang sama, yaitu akhir dari akhir, yang menyertai, menyalahkan, keadaan, klarifikasi, penegasan dan kinerja, yaitu apa yang menyebabkan tindakan yang diperlukan untuk makna transitif. Adapun preposisi "dalam” artinya adalah yang menunjukkan keadaan, pengiring, penalaran, keunggulan, analogi, mencari pertolongan, tujuan akhir, penekanan, dan makna "tentang". Dan menggali makna ini sangat penting dalam memahami dan menerjemahkan berbagai teks Arab.

Kata kunci: Kata Depan; Bahasa Arab; Kata Keterangan 


\section{PENDAHULUAN}

Preposisi dalam bahasa Arab disebut harf al-jarr, sedangkan harf al-jarr sendiri salah satu bahagian atau jenis dari hurufal-ma'aniy, dan huruf al-ma'aniy dalam bahasa Indonesia disebut Kata Tugas.

Hurûf al-maânî dapat dibagi dalam beberapa kategori, ${ }^{1}$ yaitu: (1) hurûf al-istiqbâl, seperti in, al-sîn, (2) hurûf al-tahhdhidh seperti 'alâ, (3) hurûf al-tanbîh sepert ama, (4) hururuff al-ta'kîd, seperti inna, (5) hhurûf al-jawâb seperti ajal, (6) hlurûf al-syarth seperti in, (7) hururûf al-mashdar seperti an, (8) hhurûf al-nafy seperti lâ, (9) hurûf al-ziyâdah seperti min, (10) hiurûf al-mufâjaah seperti idz, (11) hurûf al-nidâ' seperti ya, (12) hurûf al-jarr seperti min, (13) hurûf al-athf seperti waw, (14) hururfif al-istitsnâ'seperti illâ, (15) harf al-ta'nîts, (16) al-khitâb wa al-ghaibiyyah dan (17) harf al-istidrâk.

Kata tugas (huruf al-ma'ani) berfungsi membantu untuk menghubungkan verba dan nomina dalam menyempurnakan suatu makna serta membangun struktur kalimat secara lebih sempurna.

Selanjutnya dari paparan tersebut, dapat dilihat posisi hurûf al-jarr (preposisi) sebagai

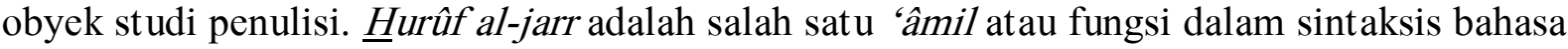
Arab yang senantiasa mengiringi ism (nomina) dalam struktur kalimat, yang maknanya sangat tergantung kepada kata yang lainnya dalam sebuah kalimat. Otoritas hukumnya dalam hukum i'râb adalah men-jarr-kan ism (nomina) yang terletak sesudahnya.

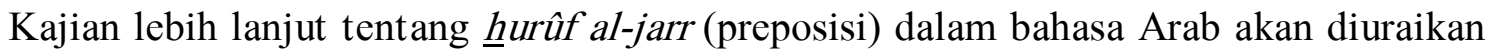
pada pembahasan berikutnya.

\section{PENGERTIAN PREPOSISI BAHASA ARAB}

Pengertian preposisi menurut istilah dalam bahasa Indonesia mempunyai pengertian yang beragam oleh para ahli bahasa Indonesia. Menurut Kridalaksana, preposisi adalah kategori yang terletak di depan kategori lain terutama nomina, sehingga terbentuk frase eksosentris.2 Dalam buku Tata Bahasa Baku Bahasa Indonesia yang diterbitkan oleh Departemen Pendidikan dan Kebudayaan RI dikatakan bahwa preposisi atau kata depan adalah kata tugas yang berfungsi sebagai unsur pembentuk frasa preposisional. ${ }^{3}$

Selanjutnya Hasan Alwi, dkk., memberi pengertian preposisi sebagai kata yang bertugas menghubungkan antara dua unsur bahasa, dan dari preposisi itu dapat dibentuk frasa preposisional. ${ }^{4}$

Abdul Chaer juga mengatakan bahwa preposisi adalah kata atau gabungan kata yang berfungsi menghubungkan kata atau frasa sehingga terbentuk sebuah frasa eksosentris, yakni frasa yang lazim menduduki fungsi keterangan di dalam kalimat. ${ }^{5}$ Hal ini dapat dicontohkan dalam sebuah kalimat yang berbunyi: "Kami baru datang dari Medan".

Kelompok kata "dari Medan" adalah frasa eksosentrik yang menduduki fungsi keterangan di dalam kalimat tersebut.

\footnotetext{
${ }^{1}$ Al-Sayyid Aḥmad Hâsyimî, al-Qawaid al-Asâsiyyah li al-Lughah al-`Arabiyyah, h. 363-364. Lihat pula
} Muhammad Hamâsah `Abd. al-Lathîf, dkk., al-Naḩw al-Asâsiy, h. 201-233.

${ }^{2}$ Harimurti Kridalaksana, Kelas Kata dalam Bahasa Indonesia, h. 175.

${ }^{3}$ Departemen Pendidikan dan Kebudayaan RI, Tata Bahasa Baku Bahasa Indonesia, h. 230.

${ }^{4}$ Hasan Alwi, dkk., Tata Bahasa Baku Bahas Indonesia, (Jakarta: Balai Pustaka, 2000), h. 288.

${ }^{5}$ Abdul Chaer, Penggunaan Preposisi dan Konjungsi Bahasa Indonesia, h. 23. 
Pengertian-pengertian yang telah dikemukakan oleh para ahli tersebut di atas, secara lahiriah, tampaknya berbeda satu sama lain, akan tetapi meskipun demikian bahwa pengertian-pengertian tersebut tetap mempunyai unsur-unsur persamaan sebagai berikut:

a. Masing-masing menunjukkan bahwa preposisi itu adalah berfungsi sebagai penghubung kata atau frasa.

b. Masing-masing menegaskan bahwa preposisi itu membentuk frasa preposisional dalam kalimat yang dapat membentuk keterangan.

Dalam konteks Arab, kata harf mempunyai dua pengertian. Pengertian pertama, menunjuk kepada arti "huruf" sebagai suatu lambang dalam bahasa yang menunjukkan suatu bunyi, seperti I (alif), ب (al-ba'). Dengan demikian, kata harf dalam pengertian ini menunjukkan arti "satu huruf" dan kata $\underline{h} u r u ̂ f$ dalam bentuk jamak menunjukkan arti "hurufhuruf atau banyak huruf". Huruf dalam pengertian ini lazim disebut hurûf hijâ'iyyah الحروف) (الهجئية) yang berjumlah 29. ${ }^{6}$ Kata $\underline{h}$ arf dalam pengertian kedua adalah "kata tugas", yaitu kata yang menunjukkan kepada satu makna dengan fungsi tertentu, seperti من (dari), لكن (tetapi) dan lain-lain. Selain istilah "partikel" biasa juga dikatakan "kata tugas". ${ }^{7}$ Kata harf dalam bentuk tunggal menunjukkan arti sebuah partikel, sedangkan $\underline{h u n \bar{f}}$ dalam bentuk jamak menunjukkan arti banyak atau beberapa kelompok partikel atau kata tugas, seperti: hurûf alnashb, hurûf al-jazm, dan hurûf al-jarr itu sendiri.

Dalam sintaksis bahasa Arab atau ilm nahw, istilah $\underline{h a r f}$ al-jarr (preposisi) dimaksudkan sebagai sekelompok kata dari hurûf sebagaimana akan dijelaskan pada pasal berikutnya yang secara fungsional menjadikan nomina (ism) dibaca dengan jarr. Dinamakan harf al-jarr disebabkan karena dua hal. ${ }^{8}$ Pertama, karena sesungguhnya kelompok $\underline{h} u r u ̂ f$ tersebut menarik atau membawa makna verba (fil) yang terdapat sebelumnya kepada makna nomina (ism) yang terdapat sesudahnya. Implikasi dari pengertian ini membawa kepada pengertian bahwa hurûf atau preposisi itu selalu didahului oleh verba (fil) dan mempunyai kaitan makna dengan verba itu, yang dalam istilah nahw disebut mutaalliq, mempunyai keterkaitan pengertian. Kedua, ialah bahwa hurûf al-jarr (preposisi) tersebut menjadikan kata benda sesudahnya dibaca dengan jarr. Ini membawa kepada pengertian bahwa hurûf al-jarr atau preposisi itu tidak harus didahului oleh verba (fil). ${ }^{9}$

Selanjutnya menyangkut tentang ragam atau jenis-jenis preposisi akan dijelaskan pada fasal berikut ini.

\section{JENIS-JENIS PREPOSISI BAHASA ARAB}

Setelah penulis memaparkan pengertian preposisi (hurûf al-jarr) sebagaimana tersebut di atas, maka pada pasal ini penulis akan menguraikan jenis-jenis preposisi menurut para ahli bahasa Arab. Penetapan jenis-jenis dan jumlah preposisi (hurûf al-jarr) di kalangan para ahli bahasa tampaknya bervariasi. Di antara mereka, ada yang menetapkan 17 (tujuh belas)

6 Ahmad Thib Raya dan Musdah Mulia, al-Asâs fi al-Lughah al-`Arabiyyah, (Jakarta: Paradotama Wiragemilang, 1999), h. 24.

7 Abdul Chaer, Penggunaan Preposisi dan Konjungsi Bahasa Indonesia, h. 11. Ida Bagus Putrayasa, Analisis Kalimat, Fungsi, Kategori dan Peran, (Bandung: PT. Refika Aditama, 2007), Cet. I, h. 85. Hasan Alwi dkk., Tata Bahasa Baku Bahasa Indonesia, h. 288.

${ }^{8}$ Syekh Musthafâ al-Ghalayainî, Jâmi al-Durûs al-`Arabiyyah, (Beirut: Dâr al-Maktabah al-Ahalliyyah, 1939), Jilid III, Cet. IV, h. 166. Yas bin Zain al-Dîn al-‘Alimî al-Humsâ, Syarh al-Tashrîf 'Alâ Taudhîb, Beirut: Dâr al-Fikr, t.th.) Juz II, h. 2.

${ }^{9}$ Ahmad Thib Raya, Hurûf al-Jarr dalam al-Qur'ân, h. 10. 
macam, sementara yang lainnya menyatakan 18 (delapan belas) macam, 19 (sembilan belas), dan 20 (dua puluh) macam. Keragaman tersebut dapat dilihat dalam uraian di bawah ini.

Fuad Nimah, dalam bukunya yang berjudul Mulakhkhas Qawâ'id al-Lughah al'Arabiyyah mengatakan bahwa hurûf al-jarr itu berjumlah 17 macam, yaitu: (1) al-ba' (الباء)),

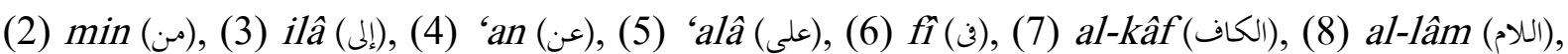

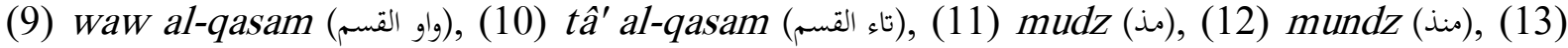

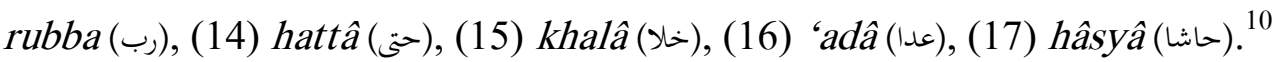

Pendapat ini sejalan pula dengan Muhammad Hamâsah 'Abd al-Lathîf dkk., dalam bukunya yang berjudul Al-Nahww al-Asâsiy, ia menuls bahwa preposisi itu 17 macam, meskipun urutan preposisi tersebut berbeda. ${ }^{11}$

Berbeda dengan Fu'âd Nimah, Ahmad al-Hâsyimî mengutarakan bahwa hurûf al-jarritu

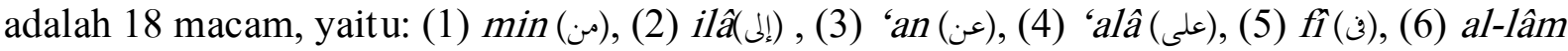

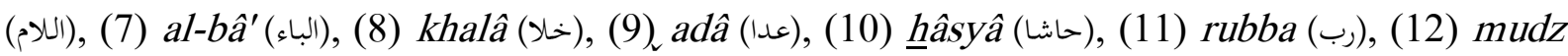

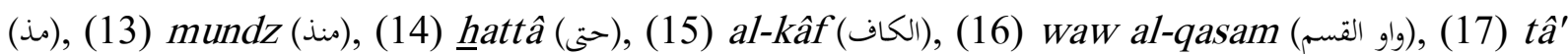

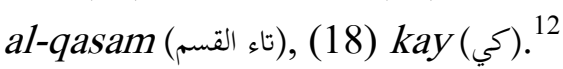

Dalam Mujam Qawâ'id al-Lughah al-'Arabiyyah fî Jadâwul wa Lawhât, dikemukakan bahwa preposisi itu berjumlah 19 (sembilan belas) macam yaitu: (1) ilâ (إلى), (2) al-bâa' (الباء),

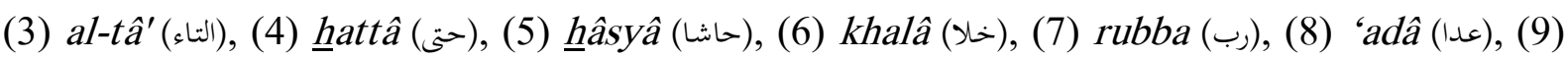

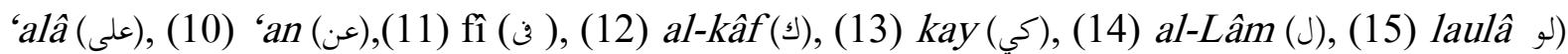

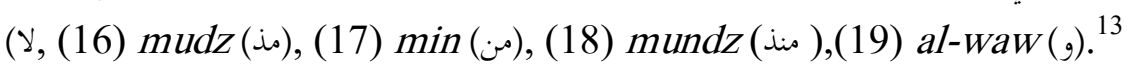

Sementara itu, Abbas Hasan dalam bukunya berjudul al-Naḥw al-Wâfî menulis bahwa

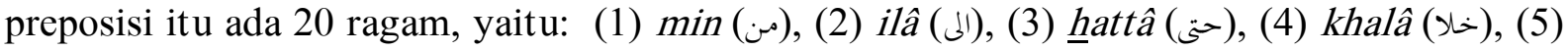

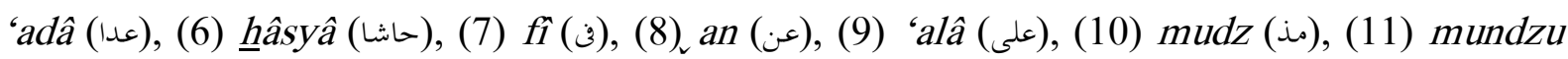

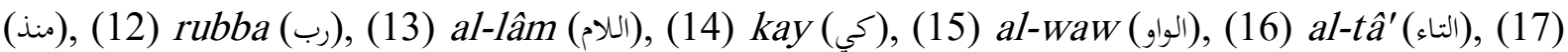

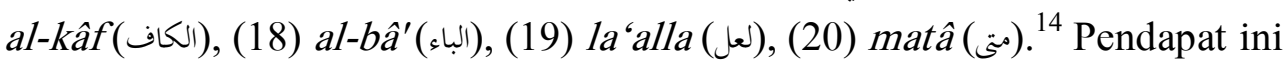

Sama dengan pendapat 'Ashîm Bahjat al-Baythâr dkk. mengatakan bahwa preposisi itu berjumlah dua puluh jenis, ${ }^{15}$ meskipun penyebutan preposisi tersebut, urutannya berbeda. Demikian pula Mustafâ al-Ghalayainî mengatakan bahwa preposisi itu berjumlah dua puluh macam. ${ }^{16}$

\footnotetext{
${ }^{10}$ Lihat Fuâd Ni‘mah, Mulakhkhas Qawâ'id al-Lughah al- 'Arabiyyah, h. 148.

${ }^{11}$ Muhammad Hamâsah 'Abd al-Lathîf dkk., al-Nahww al-Asâsiy h. 202.

12 Al-Sayyid Aḥmad Hâsyimî, Al-Qawâ ’id al-Asâsiyyah li al-Lughah al-`Arabiyyah, h. 263-264.

${ }^{13}$ Antoine Dahdah, diedit oleh Jûraj Mitriy 'Abd al-Masîh, Mu jam Qawầid al-Lughah al-'Arabiyyah fî Jadâwil wa Lawhât, (Beirut: Maktabah, Lubnan, 1981), Cet. I, h. 26.

${ }^{14}$ Abbâs Hasan, al-Nahrw al-Wâfî, Jilid II, Cet. IV, h. 431.

15 'Ashim Bahjah al-Baythâr, dkk., Syarh Ibn 'Aqîl, h. 230. Lihat pula Ibnu Hisyâm al-Anshârî, 'Audha $\underline{h}$ al-Masâlik Ilâ Al-Fiyyah Ibn Mâlik, tahqî̀q: Muhammad Muhyi al-Dîn“Abd al-Hamîd, (Beirut: al-Maktabah alAshriyyah, t.t.), Juz III, h. 5.

${ }^{16}$ Musthafâ al-Ghalayainî, Jâmi 'al-Durûs al-'Arabyyah, h. 165. Lihat pula Azîzah Fuwwâl bi Abatî, alMu jam al-Mufashshal fî al-Nahww al-`Arabiy, Juz I, h. 467-468.
} 
Penetapan jumlah preposisi di kalangan para ahli bahasa, khususnya ahli nahw tersebut, meskipun kelihatannya berbeda akan tetapi tidaklah bertentangan. Perbedaan itu hanya terjadi pada tiga jenis hurûf, yaitu: $\operatorname{kay}(5)$, matâ(متى), dan laalla(لعل).

Menurut penulis, Fu'âd Ni'mah misalnya tidak memasukkan ketiga jenis hurûftersebut

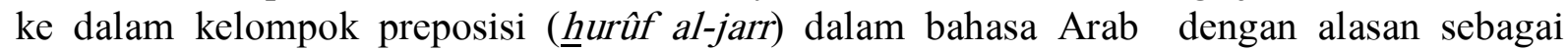
berikut:

a. $\operatorname{Kay}(ك)$ tergolong sebagai salah satu jenis harf mashdariyin wa nashb. ${ }^{17}$

b. Matâ (متى) tergolong sebagai salah satu jenis harf al-jazm,. ${ }^{18}$ bahkan selain itu ia juga berfungsi sebagai salah satu harf al-istifhâm.

c. Laalla (لعل) tergolong sebagai salah satu harf dari al-hiurûf al-musyabbahah bi al-âfâl, yang merupakan kelompok inna. ${ }^{19}$ Bahkan menurut Muhammad bin Muhammad alRaînî al-Syahîr bi al-Haththâb menyatakan bahwa preposisi bahasa Arab itu hanya berjumlah 14 macam. Ia tidak menggolongkan tiga huruf terakhir, yaitu: khalâ, adâ dan hâsyâ karena huruf-huruf tersebut disamping dapat dianggap sebagai preposisi juga dipandang sebagai huruf al-istitsnâ, ${ }^{20}$ bukan preposisi semata-mata.

Berbeda halnya dengan para ahli yang lain, Ahmad al-Hasyimî misalnya menggolongkan kay (كي) itu sebagai salah satu dari kelompok harûf al-jarr sehingga menurutnya, bahwa preposisi atau hurûf al-jarr itu berjumlah 18 (delapan belas) jenis.

Selanjutnya, golongan yang lain seperti Abbas Hassan, sebagaimana tersebut di atas, menggolongkan kata la'alla (لعل) dan matâ (متى) tersebut ke dalam kelompok preposisi sehingga jumlah preposisi itu mencapai 20 (dua puluh) dengan alasan sebagai berikut:

a. Lafaz la'alla terhitung sebagai salah satu jenis preposisi atau harf al-jarr bagi bahasa bangsa atau suku 'Uqail.

b. Lafaz matâ terhitung sebagai salah satu jenis preposisi bagi bahasa bangsa atau suku Hudzail. Lafaz matâ searti dengan "min".

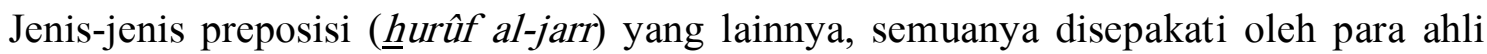
bahasa kendatipun penempatan atau urutan-urutan penyebutan preposisi tersebut berbeda di kalangan mereka.

\section{MAKNA-MAKNA PREPOPISI LOKATIF BAHASA ARAB}

Jika pada pembahasan sebelumnya telah dikemukakan jenis-jenis preposisi dalam bahasa Arab, maka pada bagian ini akan dipaparkan secara mendetail makna-makna preposisi lokatif bahasa Arab, yaitu min, ilâ, dan fî. Preposisi tersebut dinamakan Lokatif karena bertalian dengan mkna tempat dan dapat bersinergi dalam suatu kalimat, misal:

${ }^{17}$ Yang dimaksud hurûf al- nashb adalah salah satu 'âmil yang menjadikan fi'l mudlâri'dibaca dengan nashb. Yang termasuk hurûf al-nashb adalah an, lan, idzan, dan kay. Lihat al-Sayyid Ahmad al-Hâsyimî, alQawâ'id al-Asâsiyyah li al-Lughah al Arabiyyah, h. 336.

${ }^{18}$ Yang dimaksud harf al-jazm adalah salah satu ‘âmil yang menjadikan fi l mudlâri` itu di-jazm. Yang termasuk harf al-jazm adalah in, idzma, man, mâ, mahmâ, ayyâna, kaifamâ, matâ, aenamâ, ayyâna, annâ, haitsumâ. Lihat al-Sayyid Ahmad al-Hâsyimî, al-Qawâ 'id al-Asâsiyyah li al-Lughah al- 'Arabiyyah, h 343-344.

${ }^{19}$ Yang dimaksud hurûf al-musyabbahah bi al-af'âl (kelompok inna) adalah salah satu ‘âmil yang menashb-kan ism dan me-rafa-kan`khabar. Yang termasuk huruf ini adalah inna, anna, kaanna, lakinna, laita, dan la 'alla. Lihat al-Sayyid Ahmad Hasyimî, al-Qawâ 'id al-Asâsiyyah li al-Lughah al-`Arabiyyah, h. 160.

20 Muhammad bin Muhammad al-Ra`înî al-Syahîr bi al-Haththâb, al-Kawâkib al-Durriyyah `alâ Mutammimah al-Ajrûmiyyah, h. 49-52. 

berikut:

Makna-makna preposisi tersebut, dapat dilihat dalam uraian di bawah ini, sebagai

\section{Padanan Preposisi Lokatif Bahasa Arab dalam Bahasa Indonesia}

Untuk mengungkap makna-makna preposisi tersebut perlu dijelaskan sebelumnya padanan preposisi lokatif tersebut ke dalam bahasa Indonesia sebagai berikut:

Padanan Preposisi Bahasa Arab dan Bahasa Indonesia

\begin{tabular}{|c|c|c|c|}
\hline No & $\begin{array}{c}\text { Preposisi } \\
\text { Bahasa Arab }\end{array}$ & Makna & Preposisi Bahasa Indonesia \\
\hline \multirow[t]{13}{*}{1} & \multirow[t]{13}{*}{$\operatorname{Min}($ (من) } & 1. Ibtidâ al-Gâyah & $\begin{array}{l}\text { Asal atau permulaan tujuan/batas yang } \\
\text { menunjukkan tempat, waktu, bahan, } \\
\text { pelaku: dari, mulai, sejak. }\end{array}$ \\
\hline & & 2. al-Tabîdh & Sebahagian: di antara, antara lain \\
\hline & & $\begin{array}{l}\text { 3. al-tabyîn/Bayân } \\
\text { al-Jins }\end{array}$ & $\begin{array}{l}\text { Penjelasan tentang jenis atau hal: yaitu, } \\
\text { yakni. }\end{array}$ \\
\hline & & $\begin{array}{l}\text { 4. al-Talîl wa al- } \\
\text { Sababiyyah }\end{array}$ & ebab, karena. \\
\hline & & 5. al-Badal & Pengganti/pergantian: dari, daripada. \\
\hline & & 6. al-fashl & $\begin{array}{l}\text { Pemisahan antara dua barang atau hal: dan, } \\
\text { daripada. }\end{array}$ \\
\hline & & 7. al-Mujâwazah & $\begin{array}{l}\text { Melewati, melebihi sesuatu, dan lain-lain: } \\
\text { dari, sebab, setelah. }\end{array}$ \\
\hline & & 8. al-Ilshâq & Melekat/penyertaan: dengan, bersama. \\
\hline & & 9. al-Zharf & Tempat atau waktu: di, pada, dari. \\
\hline & & 10. al-Istila & Dianggap tinggi: di atas, dari. \\
\hline & & 11. al-Qasm & Sumpah: demi. \\
\hline & & 12. al-Tajrîd & $\begin{array}{l}\text { Penegasan atau perbandingan: sebagai, } \\
\text { seperti, laksana. }\end{array}$ \\
\hline & & 13. al-Ta'kîd & Penegasan dengan partikel: pun. \\
\hline \multirow[t]{7}{*}{2} & \multirow[t]{7}{*}{$\operatorname{IIâ}(\mathrm{l} !)$} & 1. Intihâ al-Gâyah & $\begin{array}{l}\text { Akhir tujuan/batas sesuatu, baik berkaitan } \\
\text { dengan waktu, tempat dan lain-lain: ke, } \\
\text { sampai, hingga, sampai dengan. }\end{array}$ \\
\hline & & 2. al-Musâhabah & Penyertaan: dengan, bersama \\
\hline & & 3. al-Lâm & Kepemilikan: untuk, buat, bagi \\
\hline & & 4. al-Zharfiyyah & $\begin{array}{l}\text { Keterangan tempat atau waktu: di, } \\
\text { dalam,pada. }\end{array}$ \\
\hline & & 5. al-Tabyîn & $\begin{array}{l}\text { Penjelas, semakna dengan ind: pada, untuk, } \\
\text { oleh. }\end{array}$ \\
\hline & & 6. al-Ta'kîd & Penegasan dengan artikel: pun. \\
\hline & & 7. al-Tadiyah & Transitif: zero. \\
\hline \multirow[t]{4}{*}{3} & \multirow[t]{4}{*}{$F \hat{1}(\hat{)})$} & 1. al-Zharfiyyah & Keterangan: di, dalam, pada. \\
\hline & & 2. al-Mushâhabah & $\begin{array}{l}\text { Penyertaan atau kebersamaan: bersama, } \\
\text { dengan. }\end{array}$ \\
\hline & & 3. al-Tălîl & Sebab: karena, sebab. \\
\hline & & 4. al- Istilâ & Dianggap tinggi: di atas, pada. \\
\hline
\end{tabular}




\begin{tabular}{ll}
\hline 5. al-Muqâyasah & $\begin{array}{l}\text { Perbandingan: seperti, laksana, bagi, } \\
\text { daripada. }\end{array}$ \\
\cline { 2 - 2 } \begin{tabular}{l} 
6. al-Istiânah, \\
\hline $\begin{array}{l}\text { 7. Intihâ } \\
\text { ghâyah(ilâ) }\end{array}$
\end{tabular} & $\begin{array}{l}\text { Penggunaan atau alat: dengan, bersama. } \\
\text { Akhir tujuan/batas sesuatu: ke, sampai, } \\
\text { hingga. }\end{array}$ \\
\hline $\begin{array}{ll}\text { 8. al-ta'kîd } \\
\text { 9. an }\end{array}$ & Penegasan dengan partikel: pun. \\
\hline
\end{tabular}

Dari uraian di atas dapat dipahami bahwa tidak semua preposisi bahasa Arab dapat ditemukan padanannya dalam preposisi bahasa Indonesia, misalnya preposisi min dalam makna al-tabîdh dan al-ta'kîd. Pemahaman kesepadanan antara preposisi bahasa Arab dan bahasa Indonesia sangat perlu diketahui untuk menghasilkan pemahaman makna yang baik.

\section{Makna-makna Preposisi Lokatif Bahasa Arab dalam Bahasa Indonesia}

\section{a. Makna-makna preposisi min (من)}

Min merupakan salah satu preposisi dalam bahasa Arab, terbagi atas dua macam, yaitu ghair al-zâid dan al-zâid. ${ }^{21}$ Kata min, dalam posisinya sebagai ghair al-zaid memiliki maknamakna, ${ }^{22}$ sebagai berikut:

1) Menyatakan ibtidâ' al-ghâyah (Permulaan tujuan atau batas) ${ }^{23}$, yaitu makna yang mengandung arti atau maksud yang menyatakan permulaan atau asal sesuatu, baik yang berkaitan dengan tempat, waktu maupun yang berkaitan dengan bahan, pelaku dan lainlain. Preposisi min dalam makna ini dapat diberi padanan "dari", "sejak"; dan jika digunakan dalam kaitannya dengan waktu maka preposisi tersebut dapat menempati posisi atau fungsi $m u d z$ (مذ) dan mundzu(منذ). Untuk jelasnya dapat dilihat dalam kalimat di bawah ini:

Contoh yang menyatakan tempat:

"Saya keluar dari kota itu."

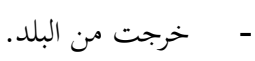

Contoh yang menyatakan waktu:

"Saya musafir sejak sore."

$$
\text { - مافرت من المساء. }
$$

${ }^{21}$ Lihat Ahmad Jamîl Syâmî Mu jam Hurûf al-Ma ânî, h. 168. Imîl Badî‘ Ya đqûb, Mawsû́ 'ah al-Hurûf fî al-Lughah al-'Arabiyyah, (Beirut: Dâr al-Jail, 1988), Cet. I, h. 466. Al-Hasan bin Qâsim al-Murâdî, al-Janâ alDânîfî̀ Hurûf al-Ma'ânî,h. 308.

${ }^{22}$ Lihat Ahmad Jamîl Syâmî, Mu jam Hurûf al-Ma`ânî, h. 168-171. Imîl Badî‘ Ya'qûb, Mawsî'ah alHurûf fî̀ al-Lughah al- 'Arabiyyah, h. 466-469. Al-Hasan bin Qâsim al-Murâdî, Al-Janâ al-Dânî fî̀ Hurûf alMa'ânî, h. 308-316. Abî al-Hasan Ali bin'Isâ al-Rûmânî al-Nahawiy, Kitab Ma'ânî al-Hurûf, (Makkah alMukarramah, 1986), h. 97-98. Al-Sayyid Ahmad al-Hâsyimî, al-Qawấid al-Asâsiyyah li al-Lughah al'Arabiyyah, h. 267-271. J.A. Haywood dan H.M. Nahmad, A New Arabic Grammar of Written Language, h. 419-420. Luis Ma'luf, Al-Munjid fî al-Lughah wa al-A 'lâm, (Beirut: Dâr al-Masyriq, 1986), Cet. XXXVII, h. 601. Ibnu Hisyâm al-Anshârîy al-Mishriy, Mughnî al-Labîb ‘an Kutub al-A 'ârib, (Beirut: al-Maktabah alMishriyyah), h. 191-192.

${ }^{23}$ Al-Sayyid Ahmad al-Hâsyimî, al-Qawâ 'id al-Asâsiyyah li al-Lughah al- 'Arabiyyah,h. 267. 
2) Menyatakan al-tab îdh (sebahagian). ${ }^{24}$ Preposisi min dalam makna ini mengandung arti atau maksud yang menunjukkan sebahagian dari keseluruhan sesuatu benda atau hal. Makna ini dapat diberi padanan: "di antara", "antara lain", "sebahagian". ciri-cirinya adalah dapat di-taqdir-kan dengan kata $b a^{\prime} d h$ (بعض). Untuk jelasnya dapat dilihat dalam contoh di bawah ini:

3)

\section{"Makanlah sebagian dari makanan ini."}

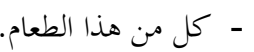

4) Menyatakan al- tabyîn atau bayân al-jins (penjelasan). ${ }^{25}$ Preposisi min dalam hal ini, mengandung arti atau maksud yang ingin menjelaskan sesuatu atau hal yang sifat atau jenisnya masih umum, kurang jelas. Padanan yang dapat diberikan untuk makna ini biasanya dilesapkan atau diberi kata penjelas, seperti kata "yaitu", "berupa". Makna seperti ini dapat dilihat dalam kalimat di bawah ini:

"Saya membeli satu pound susu."

$$
\begin{aligned}
& \text { - إشتريت رطلا من اللبن. } \\
& \text { ـ واجتوا الرجس من الأوثان. الحج: } 3
\end{aligned}
$$

"Jauhilah (penyembahan) berhala-berhala yang najis itu"

Selain itu, min bayân al-jins seringkali digunakan untuk menjelaskan kata ma(almaushul) yang terdapat sebelumnya. Cara menerjemahkan preposisi min tersebut, sebaiknya diposisikan atau diletakkan bersama nomina yang majrûr pada kata mâ. ${ }^{26}$ Padanan preposisi min dalam makna tersebut dilesapkan. Contoh:

$$
\text { . أن ان ما تحقق محمد من نجاح ليس من عمل يده. }
$$

\section{"Sesungguhnya keberhasilan yang dicapai Muhammad bukan semata-mata dari usahanya sendiri".}

5) Menyatakan al-ta'lîl (sebab). ${ }^{27}$ Yaitu makna yang mengandung arti atau maksud yang menerangkan tentang sebab terjadinya sesuatu. Preposisi ini dapat diberi padanan "sebab", "karena". Sebagai contoh dapat dilihat dalam kalimat di bawah ini:

$$
\begin{aligned}
& \text { "Dia meninggal disebabkan karena مات من الخوف. - } \\
& \text { takut." }
\end{aligned}
$$

6) Menyatakan badal (penggantian atau pilihan). ${ }^{28}$ Makna ini bukan menunjukkan badal dalam konteks ilmu nahw, akan tetapi mengandung arti atau maksud yang merupakan

${ }^{24}$ Al-Sayyid Ahmad al-Hâsyimî, al-Qawầid al-Asâsiyyah li al-Lughah al-`Arabiyyah,h. 267. Mushthafâ al-Ghalayainî, Jâmi al-Durûs al-`Arabiyyah, juz I, h. 172. W.Wright LL.D, A Grammar of the Arabic Language, Jilid II, h. 137.

${ }^{25}$ Mushthafâ al-Ghalayainî, Jâmi al-Durûs al-`Arabiyyah, juz I, h. 172. Abbas Hasan, al-Nahww al-Wâfî, Juz II, h. 459. J.A. Haywood dan H.M. Nahmad, A New Arabic Grammar of the Written Language, h. 420.

${ }^{26}$ J.A. Haywood dan H.M. Nahmad, A New Arabic Grammar of the Written Language, h. 420-421.

${ }^{27}$ Abbas Hasan, al-Nahww al-Wâfî̀, Juz II, h.463. Mushthafâ al-Ghalayainî, Jâmi`al-Durûs al-`Arabiyyah, juz I, h. 173.

${ }^{28}$ al-Sayyid Ahmad al-Hâsyimî, Al-Qawầid al-Asâsiyyah li al-Lughah al- Arabiyyah,h. 267. Mushthafâ al-Ghalayainî, Jâmi`al-Durûs al-`Arabiyyah, juz I, h. 172. 
pilihan di antara dua hal atau lebih. Preposisi min dalam makna ini dapat diberi padanan dengan "dan", "dari pada". Sebagai contoh dapat dilihat dalam ungkapan berikut ini:

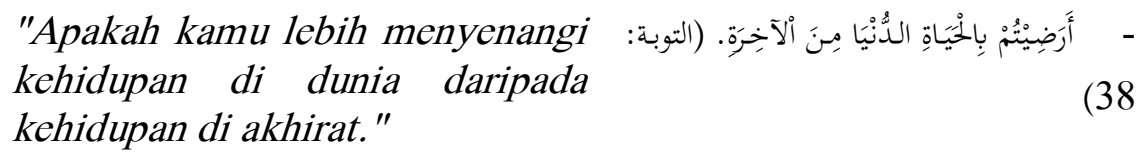

Lafaz بدل الآخرة Dengan demikian من الآخرة tersebut dinamakan min al-badaliyah.

7) Menyatakan al-fashl (pemisah) ${ }^{29}$. Makna ini mengandung arti atau maksud, yang memisahkan antara dua barang atau perkara yang karakternya berbeda atau bertolak belakang. ${ }^{30}$ Bila preposisi ini dietrjemahkan dalam bahasa Indonesia dapat diberi padanan "dan", "daripada". Sebagai contoh dapat dilihat dalam ungkapan di bawah ini:

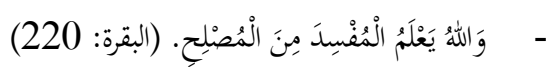

"Allah mengetahui orang yang berbuat kerusakan dan yang berbuat kebaikan."

8) Menyatakan al-mujâwazah atau al-muzâwalah (melewati, menjauh). ${ }^{31}$ Makna ini mengandung arti atau maksud yang ingin menjelaskan sesuatu atau hal yang menunjukkan sudah lewat atau menjauh dari sesuatu. Preposisi min dalam hal ini mempunyai makna yang sama dengan 'an (عن) yang dapat dipadankan dengan "dari", "setelah", dan "sebab". ${ }^{32}$ Untuk jelasnya makna tersebut dapat dicermati dalam kalimat di bawah ini:

"Yang memberi makan kepada
mereka karena lapar"

"Dan mengamankan mereka dari rasa ketakutan"

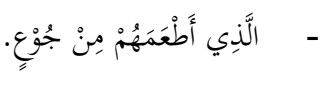

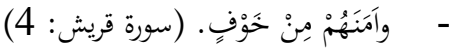

Makna al-mujâwazah bagi preposisi min tersebut, juga dapat ditemukan dalam fil yang menunjukkan al-tafdhîl(perbandingan) ${ }^{33}$. Untuk jelasnya dapat dilihat dalam contoh di bawah ini

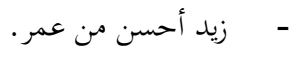

Kalimat ini setara dengan:

${ }^{29}$ Imîl Badî Yàqûb, Mawsû 'ah al-Hurûf fì al-Lughah al-`Arabiyyah, h.468.Lihat pula W.Wright LL.D, A Grammar of the Arabic Language, Jilid II, h. 132.

${ }^{30}$ Yang dimaksud dengan al-fashl ialah memisahkan antara dua perkara, barang. Lihat pula Ahmad Warson Munawwir, al-Munawwir Kamus Arab-Indonesia, h. 1138.

${ }^{31}$ Imîl Badî‘ Ya`qûb, Mawsû' 'ah al-Hurûf fî̀ al-Lughah al-`Arabiyyah, h.467. J.A. Haywood dan H.M. Nahmad, A New Arabic Grammar of the Written Language, h.429.

${ }^{32}$ Imîl Badî Ya`qûb, al-Mu`jam al-Mufashshal fì 'ulûm al-Lughah li al-Siniyyah, (Beirut: Dâr al-Kutub al-'Ilmiyyah, 1993), Cet. I, Jilid I, h. 676. Lihat pula Ahmad Warson Munawwir, al-Munawwir Kamus ArabIndonesia, h. 1047-1048.

33 J.A. Haywood dan H.M. Nahmad, A New Arabic Grammar of the Written Language, h. 420. Lihat pula W.Wright LL.D, A Grammar of the Arabic Language, Jilid II, h. 133. 


$$
\text { - - - - ماوز زيد عمرا في الحسن. }
$$

9) Menyatakan ilshâq (melekat). ${ }^{34}$ Yaitu makna yang mengandung arti atau maksud yang menunjukkan adanya hubungan melekat atau kedekatan anatara sesuatu dengan yang lain, baik secara lahiriyah maupun secara maknawiyah. Preposisi min dalam hal ini semakna dengan al-bấ(الباء) yang berarti "dengan". Contoh:

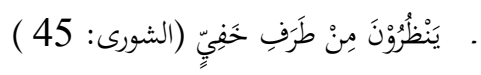

"Mereka melihat dengan pandangan yang lesu."

Kata dalam kalimat tersebut seolah-olah adalah بطن طرف) .

$$
\text { - }
$$

"Saya memukulnya dengan pedang."

10) Menyatakan zharf. $^{35}$ Makna ini mengandung arti atau maksud yang menunjukkan keterangan, baik yang berkaitan dengan waktu maupun tempat terjadinya peristiwa. Preposisi ini semakna dengan fî̀ (ف) yang dapat diberi padanan "di" atau "pada", ${ }^{36}$ contoh:

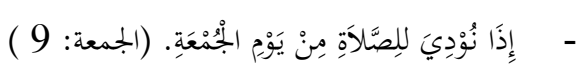

"Apabila telah diseru untuk melaksanakan shalat Jum'at, pada hari Jum'at".

11) Menyatakan al-istilâ' (dianggap tinggi). ${ }^{37}$ Makna ini mengandung arti atau maksud yang menunjukkan posisi sesuatu berada di atas yang lainnya, baik secara lahiriah maupun secara batiniah. Preposisi min dalam hal ini semakna dengan alâ (على), ${ }^{38}$ yang dapat diberi padanan "di atas", "pada". Untuk jelasnya dapat dilihat dalam contoh di bawah ini:

-

"Saya melihat buku di atas meja."

$$
\text { - }
$$

"Dan Kami menolongnya dari orang-orang yang telah mendustakan ayat-ayat Kami."

12) Menyatakan al-qasm ${ }^{39}$. Makna ini digunakan khusus untuk lafadz rabb(رب), mengandung arti atau maksud pernyataan sumpah dengan nama Allah untuk memperkuat perkataan

34 Al-Hasan bin Qâsim al-Murâdî, Al-Janâ al-Dânî fî Hurûf al-Ma ânî, 314. Imîl Badî̀ Ya qûb, Mawsû̀ ah al-Hurûf fî al-Lughah al-`Arabiyyah, h.468.

${ }^{35}$ Imîl Badî̀ Ya`qûb, Mawsû̀ah al-Hurûf fî̀ al-Lughah al-Aarabiyyah, h.468. Al-Sayyid Ahmad alHâsyimî, al-Qawầid al-Asâsiyyah li al-Lughah al-`Arabiyyah, h.170.

36 ‘Azîzah Fuwwâl bi Abatî, al-Mu`jam al-Mufashshal fî al-Nahww al-`Arabiy, h. 602.

37 Al-Hasan bin Qâsim al-Murâdî, Al-Janâ al-Dânî fî̀ Hurûf al-Ma ânî̀, h. 313. Imîl Badî‘ Ya qûb, Mawsû‘ ah al-Hurûf fî al-Lughah al-`Arabiyyah, h.468.

38 'Azîzah Fuwwâl bi Abatî, Al-Mu jam al-Mufashshal fî al-Nahw al-`Arabiy, h. 85.

39 Imîl Badî‘ Ya`qûb, Mawsû̀ah al-Hurûf fî̀ al-Lughah al-`Arabiyyah, h.315. Al-Hasan bin Qâsim alMurâdî, al-Janâ al-Dânî fî Hurûf al-Ma`ânî, h. 170. 
dan membenarkan pembicaraan. ${ }^{40}$ Preposisi min dalam makna ini dapat diberi padanan "demi", misalnya kalimat berbunyi:

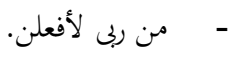

"Demi Tuhanku, saya akan melakukannya"

13) Menyatakan al-tajrîd (penegasan). ${ }^{41}$ Makna ini mengandung arti atau maksud yang ingin memberi penegasan tentang sesuatu. Kata min dalam makna ini terletak di muka sebuah nomina atau ism mutsbat yang memiliki sifat terpuji atau tercela. Misalnya:

-

"Saya memandang Zaid sebagai singa".

Preposisi min pada kalimat tersebut mempertegas keberanian Zaid.

14) Menyatakan al-ta'kîd (penegasan). ${ }^{42}$ Preposisi min dalam hal ini merupakan zâ'idah (tambahan) yang pada hakikatnya tidak mendatangkan makna baru. Makna ini bermaksud mempertegas kata yang bersifat umum ('am) yang dikandung sebuah kalimat. ${ }^{43}$ Makna ini dapat difahami dengan salah satu cirri sebagai berikut:

(1) Preposisi min tersebut didahului harf al-nafy dan harf al-istifhâm.

(2) Ism majrûr yang terletak sesudah min adalah berbentuk nakirah.

(3) Ism yang berupa majrûr itu adalah berkedudukan sebagai fầil, mấûl bih, atau mubtada. ${ }^{4}$

Contoh:

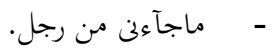

"Seorang laki-lakipun tidak datang kepada saya."

Asal kalimat tersebut sebenarnya adalah:

- ماجاءءنى رجل.

\section{b. Makna-makna Preposisi Ilâ(إلى)}

Ilâ merupakan salah satu preposisi (harf al-jarr) yang berfungsi men-jarr-kan nomina (ism), baik yang zhâhir maupun yang dhamîr. Preposisi ini dapat diberi padanan ke dalam bahasa Indonesia dengan "ke", "kepada". 45 "Ke" digunakan untuk menyatakan tempat tujuan, sedangkan "kepada" digunakan di muka kata benda (ism) yang menunjukkan orang, misalnya

40 ‘Azîzah Fuwwal bi Abatî, al-Mu jam al-Mufashshal fî al-Nahww al-`Arabiy, h. 794.

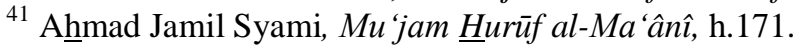

42 Al-Hasan bin Qâsim al-Murâdî, Al-Janâ al-Dânî fî̀ Hurûf al-Ma ânî, h. 316. Al-Sayyid Ahmad alHâsyimî, al-Qawâ id al-Asâsiyyah li al-Lughah al-`Arabiyyah, h. 267.

${ }^{43}$ Abbâs Hasan, Al-Nahw al-Wâfî, , Juz II, Cet. IV, h. 451. Lihat pula W.Wright LL.D, A Grammar of the Arabic Language, Jilid II, h. 135. Al-Hasan bin Qâsim al-Murâdî, al-Janâ al-Dânî fî Hurûf al-Ma ânî, h. 316. Al-Sayyid Ahmad al-Hâsyimî, al-Qawâ 'id al-Asâsiyyah li al-Lughah al-'Arabiyyah, h. 267. J.A. Haywood dan H.M. Nahmad, A New Arabic Grammar of the Written Language, h. 420.

${ }^{44}$ Lihat Imîl Badî̀ Ya`qûb, Mawsû̀ah al-Hurûf fî̀ al-Lughah al-`Arabiyyah, h. 469. Luis Ma'luf, alMunjid fì al-Lughah wa al-A lâm, h. 775. Abbâs Hasan, al-Nahww al-Wâfî̀, h. 460. Musthafâ al-Ghalayainî Jâmi` al-Durûs al-`Arabiyyah, h. 172.

${ }^{45}$ Adîb Bisri dkk., Kamus Indonesia Arab-Arab Indonesia, (Surabaya: Pustaka Progresif, 1999), Cet. I, h. 15. 
beliau, serta di muka kata benda yang menyatakan asas atau ajaran, seperti dalam kalimat: kembali kepada UUD '45 dan lain-lain. ${ }^{46}$ Selanjutnya dalam literatur Arab, preposisi ini mempunyai beberapa makna. ${ }^{47}$ Untuk jelasnya dapat dilihat dalam uraian berikut ini:

1) Menyatakan intihâ' al-ghâyah (akhir tujuan atau batas). Makna ini mengandung arti atau maksud yang menerangkan akhir tujuan atau batas sesuatu, baik yang berkaitan dengan tempat maupun yang berkaitan dengan waktu. Preposisi ilâ dalam makna ini dapat diberi padanan "ke", "sampai". Makna ini merupakan makna pokok preposisi tersebut. ${ }^{48}$ Kedudukannya dalam kalimat senantiasa mutaalliq (bergantung) pada fil atau pada kata yang semakna dengan fill, misalnya ism al-fầil, mashdar; contoh:

$$
\text { - مهبت إلى الجبل. - }
$$

"Saya pergi ke gunung".

$$
\text { - }
$$

"Kemudian sempurnakan puasa sampai (datang) malam."

2). Menyatakan al-mushâhabah (kebersamaan). Makna ini mengandung arti atau maksud yang menunjukkan kebersamaan seseorang atau sesuatu dengan yang lainnya disebabkan adanya keterkaitan atau kepentingan. ${ }^{49}$ Hal ini semakna dengan maa. Cirinya adalah posisi ( harf al-jarr) "إلى" dalam suatu kalimat dapat menempati posisi kata "مع". Padanan Preposisi ini adalah "dengan","bersama". Umpamanya kalimat berbunyi:

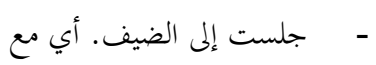

"Saya duduk bersama tamu".

3) Menyatakan al-lâm (milik). ${ }^{50}$ Yaitu makna yang mengandung arti atau maksud yang menerangkan milik atau kepunyaan. Dalam bahasa Indonesia dapat diberi padanan "untuk" atau "milik". Misalnya, ayat berbunyi:

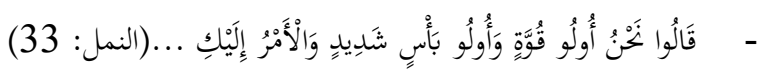

"Mereka menjawab", kita memiliki kekuatan dan keberanian yang luar biasa (untuk berperan), tetapi keputusan berada di tanganmu...".

Sebagian ahli bahasa mengatakan bahwa preposisi ilâ (إلأمر إليك pada ungkapan menunjukkan makna pokoknya, yaitu bermakna intihâ' al-ghâyah, pada hakikatnya

\footnotetext{
${ }^{46}$ Abdul Chaer, Penggunaan Preposisi dan Konjungsi Bahasa Indonesia, h. 33-34.
}

47 Al-Sayyid Ahmad al-Hâsyimî, al-Qawầid al-Asâsiyah li al-Lughah al-`Arabiyyah, h. 269-270. Imîl Badî Yàqûb, Mawsû̀ah al-Hurûf fî̀ al-Lughah al-'Arabiyyah, h. 106-108. Abi al-Hasan 'Ali bin 'Isâ al-

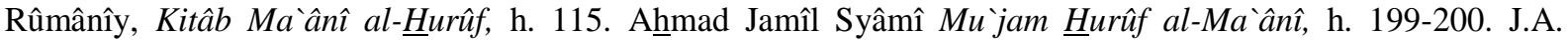
Haywood dan H.M. Nahmad, A New Grammar of Written Language, h. 414.

${ }^{48}$ Imîl Badî Yàqûb, Murâjì' al-Mu jam fì 'Ilm al-Nahnw, (Beirut: Dâr al-Kutub al-'Ilmiyyah, 1993), Cet. I, Jilid II, h. 990. Al-Sayyid Ahmad al-Hâsyimî, al-Qawầì al-Asâsiyah li al-Lughah al-`Arabiyyah, h. 269. Muhammad Hamâsah 'Abd al-Lathîf, dkk., al-Nahww al-Asâsiy, h. 203. Al-Hasan bin Qâsim al-Murâdî, al-Janâ al-Dânî fî̀ Hurûf al-Ma`ânî, h. 385.

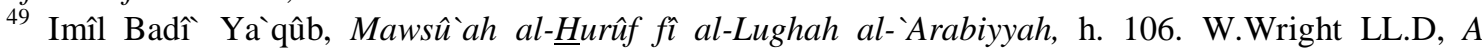
Grammar of the Arabic Language, Jilid II, h. 145.

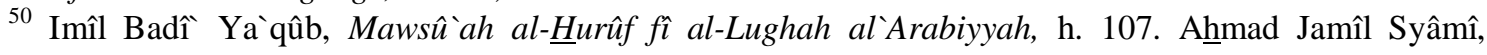

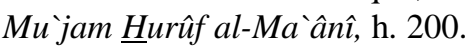


ungkapan tersebut berbunyi والأمر منته إليك, yang berarti urusan itu tergantung sampai kepada Anda. ${ }^{51}$

4) Menyatakan al-zharfiyyah (keterangan). ${ }^{52}$ Ilâ dalam makna ini mengandung arti atau maksud yang menerangkan keterangan, baik berkaitan dengan tempat maupun waktu. Dengan demikian ilâ dalam makna ini sama dengan preposisi fî yang dapat diberi padanan "di", "pada". Misalnya kalimat yang berbunyi:

$$
\text { - }
$$

"Dia (Allah) sungguh akan mengumpulkan kamu pada hari kiamat yang tidak diragukan lagi."

Preposisi ilâ yang terletak di depan/sebelum kata "يوم" dapat ditempati posisinya atau digantikan dengan kata "في" yang padanannya adalah "pada".

5) Menyatakan al-tabyîn (penjelasan) ${ }^{53}$, semakna dengan 'inda. Makna ini mengandung arti atau maksud yang berfungsi menjelaskan bahwa nomina (ism) yang datang sesudah harf ilâ adalah sebagai făil secara maknawi, bukan menurut struktur atau irab. Kata yang terletak sebelumnya berfungsi sebagai obyek penderita (maful bih) dari segi maknawi dan bukan dari segi struktur atau irab. ${ }^{54}$ Preposisi ini mutaalliq pada fil al-taajjub atau ism al-tafdlîl yang terletak sebelumnya. Padanan yang dapat diberikan untuk makna ini adalah "oleh", "menurut", dan "pada". Misalnya kalimat berbunyi:

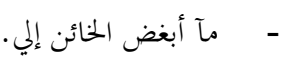

\section{"Alangkah bencinya pengkhianat itu padaku"}

6) Menyatakan ta'kîd (penegasan). ${ }^{55}$ Preposisi ilâ dalam hal ini hanya merupakan zâidah yang memberi makna ta'kîd, yang tidak mendatangkan makna baru. Dengan demikian makna ini mengandung arti atau maksud yang memberi penegasan kepada maksud kalimat. Fil yang mendahului preposisi tersebut pada dasarnya tidak memerlukan preposisi. Hal ini dapat dilihat dalam ayat di bawah ini:

$$
\text { - }
$$

"Maka jadikanlah hati sebagian manusia cenderung kepada mereka."

Lafadz هويهم" هوى sebetulnya boleh saja tidak diikuti dengan preposisi ilâ menjadi". Dengan demikian "ilâ" tersebut hanya berupa zâ'idah yang bermaksud sebagai ta'kid.

7) Menyatakan al-Tadiyah. Preposisi ilâ dalam makna ini mengandung arti atau maksud untuk menjadikan verba yang pada dasarnya bermakna intransitif (lâzim) menjadi bermakna transitif (mutaddi). Misalnya kalimat berbunyi:

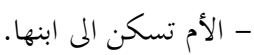

51 `Azîzah Fuwwâl bi Abatî, al-Mu jam al-Mufashshal fî al-Nahnw al-`Arabiy, Cet. I, Juz II, h. 225. Lihat pula Imîl Badî Ya`qûb, Mawsû̉ ah al-Hurûf fî al-Lughah al Arabiyyah, h. 107.

${ }^{52}$ Ahmad Jamîl Syâmî Mu jam $\underline{H}$ urûf al-Ma ânî, h. 200. Al-Sayyid Ahmad al-Hâsyimî, al-Qawâ id alAsâsiyah li al-Lughah al-`Arabiyyah, h. 270.

53 Ahmad Jamîl Syâmî, Mu jam Hurûf al-Ma ânî̀, h. 200.

${ }^{54}$ Imîl Badî‘ Ya qûb, Mawsû̀ ah al-Hurûf fì al-Lughah al-`Arabiyyah, h. 107.

55 Imîl Badî Yàqûb, Mawsû̉ah al-Hurûf fî̀ al-Lughah al-`Arabiyyah, h. 108. Ahmad Jamîl Syâmî, Mu`jam Hurûf al-Ma`ânî, h. 200. 


\section{"Ibu itu menyenangi anaknya"}

\section{c. Makna-makna Preposisi Fî(ف)}

Sebagaimana telah dijelaskan bahwa Preposisi ini merupakan salah satu preposisi yang berperan sebagai penanda letak atau tempat berada. Fungsinya dalam struktur men-jarr-kan nomina (ism), baik yang zhâhir maupun yang dhamîr yang terletak sesudahnya. Dalam bahasa Indonesia, preposisi tersebut dapat diberi padanan: di, dalam, di dalam. ${ }^{56}$ Secara lebih luas makna-makna yang dikandung oleh Preposisi fîtersebut adalah sebagai berikut:

1) Menyatakan al-zharfiyyah (keterangan). ${ }^{57}$ Preposisi fi dalam makna ini, mengandung arti atau maksud yang menunjukkan keterangan, baik keterangan yang berkaitan dengan waktu, tempat, maupun yang berkaitan dengan makna majaz atau kiasan. ${ }^{58}$ Yang dimaksud majaz atau kiasan di sini adalah keterangan yang bukan menunjukkan tempat atau waktu. Preposisi fî dalam makna ini, dapat diterjemahkan dengan padanan "di", "pada", "dalam" atau "di dalam". Makna ini merupakan makna pokok atau makna dasar, baik yang merupakan makna hakikat yang meliputi keterangan tempat dan waktu, maupun yang menunjukkan makna majaz atau kiasan.

Contoh makna hakikat:

"Air itu ada di dalam kendi."

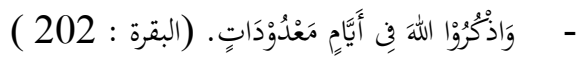

"Berdzikirlah kepada Allah pada hari yang telah ditentukan."

Contoh makna majaz:

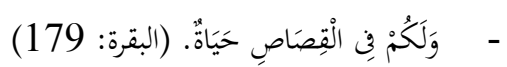

"Dan dalam qishash ini ada kehidupan bagimu."

2) Menyatakan al-mushâhabah (kebersamaan). Makna ini mengandung arti atau maksud yang menunjukkan kebersamaan antara seseorang atau sesuatu dengan yang lainnya. Preposisi fî dalam makna ini, pada hakikatnya semakna dengan maa, yang dapat diberi padanan "bersama". ${ }^{59}$ Ciri-cirinya, preposisi tersebut dapat ditempati posisinya oleh kata maa dalam sebuah kalimat. Untuk jelasnya dapat dilihat dalam contoh di bawah ini:

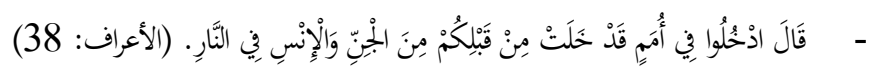

"Allah berfirman, "masuklah kamu ke dalam neraka bersama golongan jin dan manusia yang telah lebih dahulu dari kamu."

${ }^{56}$ Adîb Bisri dkk., Kamus Indonesia Arab-Arab Indonesia, h. 579. Lihat pula J.A. Haywood dan H.M. Nahmad, A New Arabic Grammar of the Written Language, h. 418.

${ }^{57}$ Al-Hasan bin Qâsim al-Murâdî, Al-Janâ al-Dânî fì Hurûf al-Ma ânî, h. 250. Al-Imâm Abi Muhammad `Abdullah Jamâl al-Dîn bin Yusuf Ibn Ahmad bin `Abdillah bin Hisyam, Mughnî al-Labîb, (Mesir: al-Maktabah al-Tijâriyyah al-Kubrâ, t. th.), Juz I, h. 168.

${ }^{58}$ Ahmad al-Hâsyimî, Al-Qawâ id al-Asâsiyah li al-Lughah al-`Arabiyyah, h. 268.

59 Aḥmad Jamîl Syâmî, Mu jam Hurûf al-Ma ânî, h. 139. Mushthafâ al-Ghalayainî, Jâmi al-Durûs al'Arabiyyah, Juz I, h. 180. Abbâs Hasan, al-Nahww al-Wâfî, Juz II, h.507. Al-Sayyid Ahmad al-Hâsyimî, alQawầid al-Asâsiyyah li al-Lughah al- 'Arabiyyah,h. 268. W.Wright LL.D, A Grammar of the Arabic Language, Jilid II, h.268. 
Lafaz "مع أمى" dapat diganti dengan "مع امث", yang artinya bersama.

3) Menyatakan al-talîl (sebab). ${ }^{60}$ Preposisi fî dalam hal ini mengandung arti atau maksud yang menerangkan sebab terjadinya suatu peristiwa; dalam bahasa Indonesia dapat dipadankan dengan "sebab", "karena", "untuk". Misalnya, dalam sebuah hadis dikatakan:

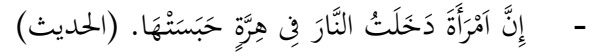

"Telah masuk seorang perempuan ke dalam neraka disebabkan karena ia mengurung seekor kucing."

Lafaz "فرة dalam hadits di atas dapat diganti dengan lafaz "بعرة". Dengan demikian preposisi fî dalam hadis di atas berarti "sebab".

4) Menyatakan al-istilâ' (dianggap tinggi). ${ }^{61}$ Makna ini mengandung arti atau maksud yang menunjukkan posisi ketinggian atau derajat sesuatu. Preposisi ini semakna dengan alâ (على) yang dapat diberi padanan "pada", "di atas". Sebagai contoh dapat dilihat dalam ayat di bawah ini:

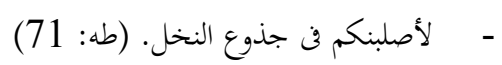

\section{"Sungguh, akan aku salib kamu pada pangkal pohon kurma."}

5) Menyatakan al-muqâyasah (perbandingan). ${ }^{62}$ Preposisi fî dalam makna ini mengandung arti atau maksud yang menunjukkan perbandingan antara sesuatu atau hal dengan yang lainnya. Posisinya terletak antara sesuatu yang tidak layak (mafdhul) dan yang layak (fâdhil) yang merupakan pilihan atau perbandingan. Sebagai contoh dapat dilihat dalam ayat berikut ini:

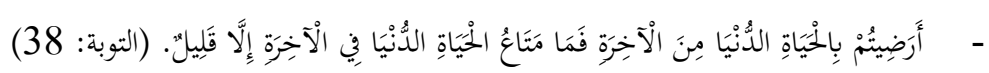

"Apakah kamu lebih menyenangi kehidupan di dunia daripada kehidupan di akhirat? Padahal kenikmatan hidup di dunia ini (dibandingkan dengan kehidupan) di akhirat hanyalah sedikit."

Kata atau frase "فالآخرة" dalam ayat di atas dapat diganti dengan frase "بالقياس إليها".

6) Menyatakan al-isțânah (penggunaan). ${ }^{63}$ Fî dalam makna ini mengandung arti atau maksud yang menunjukkan media atau alat yang menyertai pelaku dalam melakukan suatu perbuatan. Hal ini semakna dengan al-bâ', yang dapat diberi padanan "dengan". Untuk lebih jelasnya dapat dilihat dalam kalimat di bawah ini:

$$
\text { - }
$$

${ }^{60}$ Ahmad Jamîl Syâmî Mu jam Hurûf al-Ma ânî, h. 139. Lihat pula Mushthafâ al-Ghalayainî, Jâmi`alDurûs al-`Arabiyyah, Juz I, h.180. Al-Sayyid Ahmad al-Hâsyimî, al-Qawầid al-Asâsiyyah li al-Lughah al'Arabiyyah,h. 268. Al-Hasan bin Qâsim al-Murâdî, al-Janâ al-Dânî fî̀ Hurûf al-Ma ânî, h. 250.

${ }^{61}$ Abbâs Hasan, Al-Nahww al-Wâfî, Juz II, h.507.

${ }^{62}$ Mushthafâ al-Ghalayainî, Jâmi al-Durûs al-`Arabiyyah, Juz I, h.180. Lihat pula Al-Sayyid Ahmad alHâsyimî, Al-Qawầid al-Asâsiyyah li al-Lughah al- 'Arabiyyah,h. 260. Ahmad Jamîl Syâmî Mu jam $\underline{\text { Hu} u r u ̂ f ~ a l-~}$ Ma ânî, h. 139. W.Wright LL.D, A Grammar of the Arabic Language, Jilid II, h.156. Abbâs Hasan, Al-NahwwalWâfî, Juz II, h. 507.

${ }^{63}$ Abbâs Hasan, al-Nahw al-Wâfî, Juz II, h.508. Mushthafâ al-Ghalayainî, Jâmi' al-Durūs al- 'Arabiyyah, Juz I, h. 180. Aḥmad Jamîl Syâmî Mu jam Hurûff al-Ma ânî, h. 139. 
"Dia (Allah) menjadikan bagi kamu pasangan-pasangan dari jenis kamu sendiri, dan dari jenis hewan ternak pasangan-pasangan (juga). Dijadikannya kamu berkembang biak dengan jalan itu."

Frase atau kata يذركم فيه bermakna يكثركم به .

7) Menyatakan intihâ al-ghâyah (akhir tujuan/batas) ${ }^{64}$. Makna ini mengandung arti atau maksud yang menunjukkan akhir tujuan/batas terjadinya sesuatu. Preposisi fî dalam hal ini semakna dengan ilâ, yang padanannya adalah "ke", "kepada". Sebagai contoh dapat dilihat dalam ayat di bawah ini:

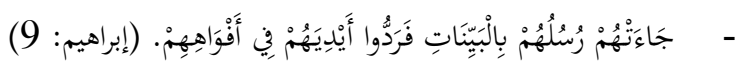

"Rasul-rasul itu telah datang kepada mereka membawa bukti-bukti (yang nyata), namun mereka menutupkan tangannya ke mulutnya."

Frase إلى أفواههم pada ayat di atas sebenarnya adalah.

8) Menyatakan al-ta'kîd (penegasan). ${ }^{65}$ Preposisi fî dalam hal ini merupakan zâ'idah yang pada dasarnya tidak mendatangkan makna baru, akan tetapi hanya bermaksud memberi penegasan tentang sesuatu. Makna ini dapat dilihat dalam kalimat di bawah ini:

- إركبوا فيها.

Asal kalimat tersebut adalah اركبوها yang pada dasarnya tidak memerlukan preposisi fî. Dengan demikian preposisi fi pada kalimat di atas merupakan zâidah yang membawa arti ta'kîd, tanpa mendatangkan makna lain.

9) Menunjukkan makna $a a^{66}{ }^{66}$ Fî dalam hal ini mengandung arti atau maksud yang sama dengan an, yang dapat diberi padanan "tentang". Menurut W.Wright bahwa preposisi ini mempunyai makna yang sama dengan about dalam bahasa Inggris. ${ }^{67}$

Jika dicermati dengan teliti tentang bentuk-bentuk dan makna-makna yang dimainkan oleh ketiga preposisi tersebut, sebagaimana tergambar dalam kalimat atau contoh-contoh yang telah dikemukakan di atas, maka dapat disimpulkan bahwa pola konstruksi atau struktur preposisi tersebut dapat dibedakan dalam beberapa bentuk sebagai berikut:

a. Pola konstruksi nominal, yaitu pola atau struktur yang mengandung preposisi yang diikuti oleh sebuah unsur nomina (ism), yang membentuk frasa dalam kalimat.

b. Pola konstruksi verbal, yaitu pola atau struktur yang mengandung preposisi dan diikuti oleh unsur nomina yang bermakna verba (fil) atau dapat berfungsi sebagai verba, yang membentuk frasa.

c. Pola konstruksi pronominal, yaitu pola atau struktur yang mengandung preposisi dan diikuti oleh kata ganti (dhamîr) yang membentuk frasa.

${ }^{64}$ Al-Hasan bin Qâsim al-Murâdî, Al-Janâ al-Dânî fî̀ Hurûf al-Ma ânî, h. 252. Imîl Badî‘ Ya qûb, Mawsû' 'ah al-Hurûf fî̀ al-Lughah al-`Arabiyyah, h. 324. Al-Sayyid Ahmad al-Hâsyimî, Al-Qawâ'id al-Asâsiyyah li al-Lughah al-'Arabiyyah,h. 269.

65 Imîl Badî Yađqûb, Mawsû̀ah al-Hurûf fî al-Lughah al-`Arabiyyah, h.324. Ahmad Jamîl Syâmî Mu jam Hurûf al-Ma'ânî, h. 140. Abbâs Hasan, al-Nahnw al-Wâfî, Juz II, h.508.

${ }^{66}$ Ahmad Warson Munawwir, Al-Munawwir, Kamus Arab-Indonesia, h. 1047.

${ }^{67}$ Lihat W.Wright, LL.D, A Grammar of the Arabic Language, Jilid II, 280. 
d. Pola konstruksi adverbial atau konjungsional, yaitu pola atau struktur yang mengandung preposisi yang diikuti sebuah kata benda adverb, atau diikuti oleh sebuah kata penghubung (mawshûl) yang membentuk frasa.

e. Pola konstruksi idiomatik, yaitu pola atau struktur yang mengandung preposisi yang berfungsi menjadikan sebuah verba intransitif menjadi verba transitif, atau sebuah preposisi diikuti kata benda adverb yang membawa makna idiom, membentuk frasa dalam kalimat.

\section{PENUTUP}

Dalam bahasa Arab, secara global kata itu terbagi ke dalam tiga jenis, yaitu kata benda (ism), kata kerja (fi'l) dan kata tugas (huruf). Huruf yang dimaksud di sini adalah huruf alma'ani tidak termasuk al-huruf al-hijaiyyah. Preposisi (harf al-jarr) adalah salah satu dari huruf al-ma'ani, yang dalam bahasa Indonesia dapat dikatakan Kata Tugas atau Partikel. Harf al-jarr ini banyak ragamnnya. Tiga di antaranya adalah min,ila, dan fi. Ketiga harf inilah yang menjadi kajian dalam tulisan ini. Selanjutnya, ketiga preposisi tersebut dapat dinamakan preposisi lokatif disebabkan karena penggunaannya dalam berbahasa senantiasa bergandengan dengan kata benda yang menunjukkan tempat atau yang sejenisnya, bahkan ketiganya dapat bersinergi dalam sebuah kalimat.

Makna preposisi min sangat beragam: menyatakan ibtida al-ghayah, al-tab'idh, altabyin, al-ta'lil, a-badal, al-fashl, al-mujawazah, al-ilshaq, al-zharf, al-isti'la, al-qasm, altajrid, al-ta'kid.

Demikian pula preposisi ila memiliki makna: intiha al-ghayah, al-mushahabah, al-lam, al-zharfiyah, al-tabyin, al-ta'kid, al-ta'diyah, dan untuk menciptakan makna muta'addi.

Sedangkan makna preposisi fi: menunjukkan: al-zharfiyah, al-mushahabah, al-ta'lil, alisti'la, al-muqayasah, al-isti'anah, intiha al-ghayah, al-ta kid dan makna 'an.

Makna-makna preposisi tersebut perlu didalami oleh setiap pembelajar bahasa Arab untuk menghindari kekeliruan dalam memahami atau menerjemahkan sebuah teks mengingat frekuensi penggunaan preposisi tersebut dalam berbahasa sangat tinggi, baik dalam bahasa lisan maupun dalam bahasa tuisan.

\section{DAFTAR PUSTAKA}

Abatî, Azîzah Fuwwâl bi, al-Mujam al-Mufashshal fî al-Nahww al-Arabiy, Beirut: Dâr alKutub al-Ilmiyyah, 1992, Cet. I, Juz II.

------, al-Mujam al-Mufashshal fî al-Nahww al-Arabiy, Beirut: Dar al-Kutub al-Ilmiyyah 1992, Cet. I., Juz I.

'Abd al-Masih, Jūraj Mitriy, Mu'jam al-Thālib wa al-Kātib, Beirut: Maktabah Lubnan, 1984, Cet. II.

Adang, Asdari, Pertukaran Huñ̄f al-Jarr dan Pengaruhnya terhadap Perubahan Makna di dalam Al-Qur'an, Thesis, Jakarta: Fakultas Pascasarjana UIN Syarif Hidayatullah, 2004.

Alisjahbana, S. Takdir, Tata Bahasa Baru Bahasa Indonesia, t.tp.: Dian Rakyat, 1973, Cet. VIII.

Budwan, Agus, Analisis Kontrastif Preposisi Bahasa Indonesia dan Bahasa Arab Serta Implikasinya dalam Pengajaran Bahasa Arab, Skripsi, Jakarta: Fakultas Bahasa dan Seni UNJ, 2000.

Kridalaksana, Harimurti, Kelas Kata dalam Bahasa Indonesia, Jakarta: PT. Gramedia Pustaka Utama, 2007 Cet. V. 
Lapoliwa, Hans, Frasa Preposisi dalam Bahasa Indonesia, Jakarta: Pusat Pembinaan dan Pengembangan Bahasa,1992.

al-Masîh, Jûraj Mitriy'Abd, Mujam Qawâaid al-Lughah al-Arabiyyah fî Jadâwil wa Lawhât, Beirut: Maktabah, Lubnan, 1981, Cet. I.

al-Murâdî, al-Hasan bin Qâsim, Al-Janâ al-Dânî fî Hurûf al-Ma'ânî, Beirut: Dār al-Kutub alIlmiyyah, 1992, Cet. I.

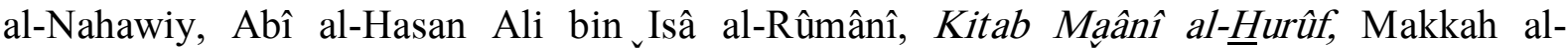
Mukarramah: t.p., 1986.

Pullum, Geoffrey K. dan Ronald, Preposition and Preposition Phareses, Cambridge: Cambridge University Press, 2000.

Ramlan, M., Kata Depan atau Preposisi dalam Bahasa Indonesia, Yogyakarta: Karyono, 1980.

Raya, Ahmad Thib, Hurûf al-Jarr dalam al-Qur'an, Pidato Pengukuhan Guru Besar, disampaikan dalam Sidang Senat Terbuka Luar Biasa IAIN, tanggal 29 Juni 1999.

Sulthânî, Muhammad Alî, Al-Adawât al-Nahwiyyâh wa Măânîhâ fî Al-Qur'ân al-Karîm, t.tp.: Dar Asma t.th.

Syâmī, Ahmad Jamîl, Mưjam Hurûf al-Maânî, Beirut: Muassasah Izz al-Dīn, 1992, Cet. I.

al-Tuwanjiy, Muhammad, dkk., al-Mujam al-Mufashshal fí Ulûm al-Lughah li al-Siniyyah, Beirut: Dâr al-Kutub al-Ilmiyyah, 1993, Cet. I, Jilid I.

Wright, W. LL.D., A Grammar of the Arabic Language, London: Cambridge University Press, 1979, Cet. IV.

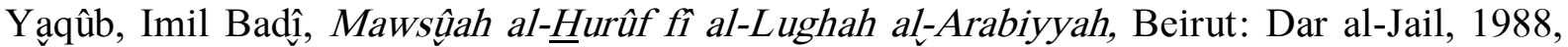
Cet. I.

, Murâji ‘ al-Mujam fị Ilm al-Nahww, Beirut: Dâr al-Kutub al-Ilmiyyah, 1993, Cet. I, Jilid I dan II. 